\title{
Effect of different climatic conditions on the degradation of historical masonry in the Czech Republic
}

\author{
J. Maděra, J. Kočí \& R. Černý \\ Department of Materials Engineering and Chemistry, \\ Faculty of Civil Engineering, Czech Technical University in Prague, \\ Czech Republic
}

\begin{abstract}
The effect of different climatic conditions on the degradation of historical masonry in the Czech Republic is studied. Several different sandstone and several different locations in the Czech Republic are selected for this analysis. The effect of environmental conditions is evaluated using various damage functions. Based on the damage function values, the most severe and most favorable locations are identified, together with the most resistant sandstone in terms of hygrothermal loads.

Keywords: sandstone, historical masonry, damage function, climatic conditions.
\end{abstract}

\section{Introduction}

Historical buildings are an integral part of contemporary cityscapes. The age of these buildings ranges from hundreds to thousands of years. With such a high age, it is inevitable to renovate these buildings in certain periods. The renovation processes are mostly controlled by monument care authorities, which insist on preservation of original treatments, technologies and materials from the period of the building's rise. Naturally, there is a significant effort of the designers and renovators to maximize the renovation periods. In order to ensure the maximum service life of the renewed construction, it is necessary to analyze the environmental conditions the constructions are exposed to. Such an analysis must be a part of the process of renovation design. The choice of proper material must be done with respect to the nature of the building; last but not least, the environmental conditions must be taken into consideration as well. Improper 
choice of the material or material composition regarding to the environment of given location may lead to a significant shortening of the service life period [1-4].

The assessment of service life of historical buildings is not an easy task as many aspects and various damage effects are to be taken into account. Such assessment cannot done on the basis of empirical knowledge. In order to obtain serious results, it is necessary to utilize some advanced techniques, for example the computational modelling $[5,6]$.

Computational modelling became very strong and powerful tool in many fields of engineering. In civil engineering, computational modelling is used within the frame of design and development of new materials, as well as for simulation and analysis of existing constructions. The biggest advantage of this kind of modelling is the fact that the studied building or its part does not have to physically exist and still, the engineers are able to study its performance from different points of view. In this way, the potential weak points of the construction may be revealed before the construction is physically built up and thus, the economic risk may be controlled more effectively, which is of double importance in case of renovation works.

Computational simulations are able to provide the hygrothermal performance of historical buildings, i.e., moisture and temperature fields within the construction, as a function of time [2]. On the basis of such performance, it is possible to seriously estimate the service life of the construction or to maximize the effect of renovation measures. The computational modelling allows effective scheduling of the renovation periods as well.

In this paper, the computational simulation is used in order to calculate the possible degradation of the historical masonry made of several different stones and located under different climatic loads typical for the Czech Republic.

\section{Computational analysis}

\subsection{Mathematical model}

For the investigation of hygrothermal performance of studied constructions a modified Künzel's mathematical model was used [7]. The model is able to distinguish more precisely between the liquid and gaseous phase of moisture transport and thus brings higher accuracy to the calculations [8]. Balance equations are expressed as:

$$
\begin{gathered}
\frac{\mathrm{d} \rho_{\mathrm{v}}}{\mathrm{d} \varphi} \frac{\partial \varphi}{\partial \mathrm{t}}=\operatorname{div}\left[\left(\mathrm{B}\left(\mathrm{D}_{\mathrm{w}} \rho_{\mathrm{w}} \frac{\mathrm{dw}}{\mathrm{d} \varphi}\right)+\mathrm{A}\left(\delta_{\mathrm{p}} \mathrm{p}_{\mathrm{s}}\right)\right) \operatorname{grad} \varphi+\left(\delta_{\mathrm{p}} \varphi \frac{\mathrm{dp}}{\mathrm{dT}}\right) \operatorname{gradT}\right] \\
\frac{d H}{d T} \frac{\partial T}{\partial t}=\operatorname{div}(\lambda \operatorname{grad} T)+L_{v} \operatorname{div}\left[\delta_{p} \operatorname{grad}\left(\varphi p_{s}\right)\right],
\end{gathered}
$$

where $\rho_{v}$ is the partial density of moisture, $\varphi$ is the relative humidity, $\delta_{p}$ is the permeability of water vapor, $p_{s}$ is the partial pressure of saturated water vapor, $H$ is the enthalpy density, $L_{v}$ is the latent heat of evaporation, $\lambda$ is the thermal 
conductivity, $T$ is the temperature, $D_{w}$ is the total capillary transport coefficient, $\rho_{w}$ is the density of water and $w$ is the moisture content. The transition function assigns the weight to parameters $A$ and $B$ (being within the range of $0-1$ ) with the balance $A+B=1$ valid for every point of the curve.

The satisfactory combination of power functions reads [8]:

$$
\begin{gathered}
\left.B=32\left[\left(\frac{1}{\varphi_{2}-\varphi_{1}}\right)\left(\varphi-\varphi_{1}\right)\right]^{6}, \text { for } \varphi=<90 ; 93.8\right), \\
B=1-32\left[\left(\frac{1}{\varphi_{2}-\varphi_{1}}\right)\left(\varphi_{2}-\varphi\right)\right]^{6}, \text { for } \varphi=<93.8 ; 97.6>,
\end{gathered}
$$

where $B=0$ for $\varphi<90 \%, B=1$ for $\varphi>97.6 \%, B \in<0 ; 1>$ according to (3) and (4) and $A=1-B$.

The solution of the transport problem leads to necessity of solving partial differential equations. These equations were solved by finite element approach using computer code SIFEL [9].

\subsection{Material parameters}

In order to demonstrate the effect of different climatic conditions on the degradation of historical masonry in the Czech Republic, the hygrothermal performance of five different sandstone masonries typical for historical buildings were investigated. The thickness of the studied load-bearing construction was $600 \mathrm{~mm}$. The studied sandstones originate from the quarries Božanov (SB), Hořice (SH), Kocbeře (SK), Libnava (SL) and Záměl (SZ). The mineralogical compositions of the sandstones are shown in Table 1. The basic physical, heat and moisture transport and storage properties are given in Table 2, where $\rho$ is the bulk density, $\psi$ the porosity, $c$ the specific heat capacity, $\mu_{d r y}$ cup the water

Table 1: Mineralogical composition of studied sandstone.

\begin{tabular}{|c|c|c|c|c|c|}
\hline & SH & SB & SK & SL & SZ \\
\hline Quartz & $73 \%$ & $78 \%$ & $83 \%$ & $71 \%$ & $79 \%$ \\
\hline Feldspar & $9 \%$ & - & - & - & $4 \%$ \\
\hline K-feldspar & - & $13 \%$ & $2 \%$ & $8 \%$ & - \\
\hline Glauconite & - & - & - & $3 \%$ & $9 \%$ \\
\hline Muscovite & $1 \%$ & $1 \%$ & $1 \%$ & - & $1 \%$ \\
\hline Rutile & - & - & $1 \%$ & - & - \\
\hline Tourmaline & $1 \%$ & $1 \%$ & $1 \%$ & - & - \\
\hline Plagioclase & - & $13 \%$ & - & - & - \\
\hline Titanite & - & - & - & $1 \%$ & - \\
\hline Zircon & $1 \%$ & $1 \%$ & - & $1 \%$ & - \\
\hline Biotit & - & $1 \%$ & - & - & - \\
\hline
\end{tabular}


vapor diffusion resistance factor in dry conditions, $\mu_{\text {wet cup }}$ the water vapor diffusion resistance factor in wet air, $\lambda_{d r y}$ the thermal conductivity in dry conditions, $\lambda_{\text {sat }}$ the thermal conductivity in water saturated conditions, $\kappa_{a p p}$ is the apparent moisture diffusivity. All the parameters were measured in the laboratories of the Department of Materials Engineering and Chemistry, Faculty of Civil Engineering, Czech Technical University in Prague and stored in the material database.

Moisture diffusivity, specific heat capacity and thermal conductivity as a function of moisture content together with sorption isotherms of studied materials were presented in $[10,11]$.

Table 2: $\quad$ Material parameters of studies sandstones $[10,11]$.

\begin{tabular}{|c|c|c|c|c|c|}
\hline & SH & SB & SK & SL & SZ \\
\hline$\rho\left(\mathrm{kg} / \mathrm{m}^{3}\right)$ & 2004 & 2154 & 2228 & 2191 & 2076 \\
\hline$\psi(\%)$ & 21.6 & 16.1 & 16.1 & 17.9 & 22.8 \\
\hline$c(\mathrm{~J} / \mathrm{kgK})$ & 712 & 672 & 760 & 628 & 694 \\
\hline$\mu_{\text {dry cup }}(-)$ & 11.59 & 13.38 & 12.7 & 11.6 & 11.8 \\
\hline$\mu_{\text {wet cup }}(-)$ & 5.77 & 7.18 & 7.4 & 7.4 & 6.9 \\
\hline$\lambda_{\text {dry }}(\mathrm{W} / \mathrm{mK})$ & 2.58 & 2.35 & 3.53 & 2.71 & 2.10 \\
\hline$\lambda_{\text {sat }}(\mathrm{W} / \mathrm{mK})$ & 3.76 & 4.54 & 5.21 & 4.64 & 3.88 \\
\hline$\kappa_{\text {app }}\left(\mathrm{m}^{2} / \mathrm{s}\right)$ & $4.14 \mathrm{e}-8$ & $2.50 \mathrm{e}-7$ & $7.17 \mathrm{e}-7$ & $5.76 \mathrm{e}-8$ & $7.76 \mathrm{e}-7$ \\
\hline
\end{tabular}

\subsection{Boundary conditions}

Boundary conditions in the interior were set constant as $21^{\circ} \mathrm{C}$ and $55 \%$ relative humidity. On the exterior side, the climatic load in a form of Test Reference Year (TRY) of five different locations was applied, namely Prague-Karlov, České Budějovice, Tušimice, Košetice, Pec pod Sněžkou and Brod nad Dyjí (see Table 3). The TRYs were obtained from the Czech Hydrometeorological Institute (CHMI) which is an official authority for climatology, hydrology and atmosphere quality in the Czech Republic. The weather data obtained from CHMI as well as other sources are stored in weather database [12]. The map of

Table 3: $\quad$ Studied localities.

\begin{tabular}{|c|c|c|}
\hline & Locality & Altitude \\
\hline 1 & České Budějovice & $385 \mathrm{~m} \mathrm{n} . \mathrm{m}$. \\
\hline 2 & Košetice & $534 \mathrm{~m} \mathrm{n.m.}$ \\
\hline 3 & Pec p. Sněžkou & $824 \mathrm{~m} \mathrm{n.m.}$ \\
\hline 4 & Praha - Karlov & $232 \mathrm{~m} \mathrm{n.m.}$ \\
\hline 5 & Tušimice & $322 \mathrm{~m} \mathrm{n.m.}$ \\
\hline 6 & Brod nad Dyjí & $177 \mathrm{~m} \mathrm{n.m.}$ \\
\hline
\end{tabular}


selected locations is shown in Fig. 1. The monthly values of relative humidity, temperature and yearly amount of precipitation typical for studied location are shown in Figs 2-4.

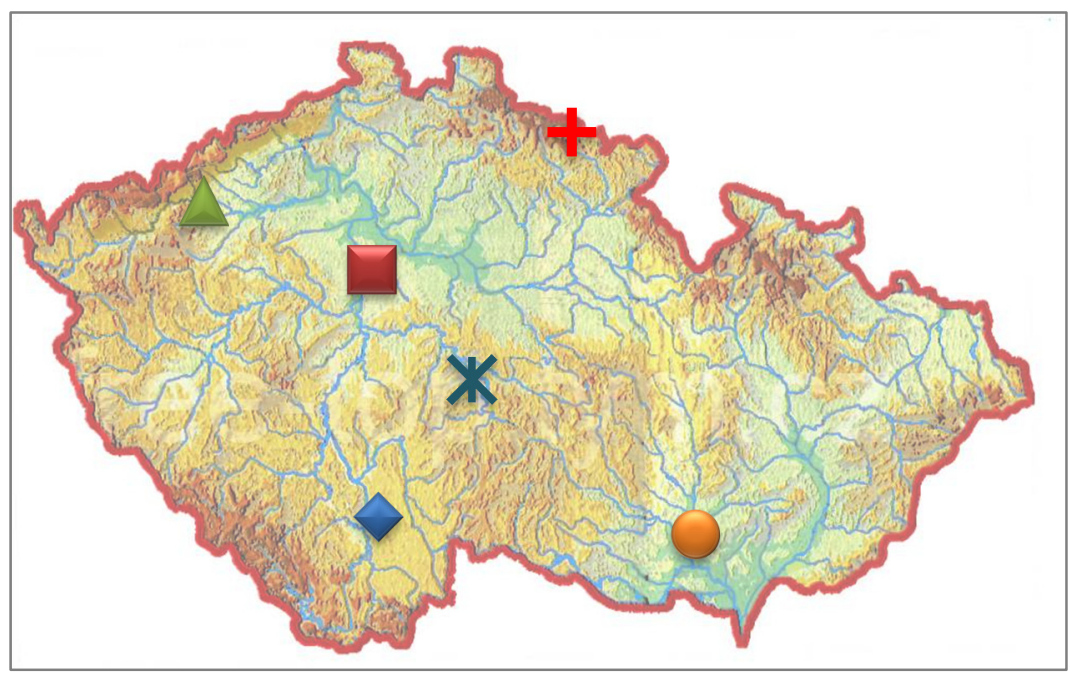
$\checkmark$ České Budějovice
- Praha-Karlov
$\Delta$ Tušimice
Mec pod Sněžkou
I Košetice
- Brod nad Dyjí

Figure 1: The map of the Czech Republic with selected localities.
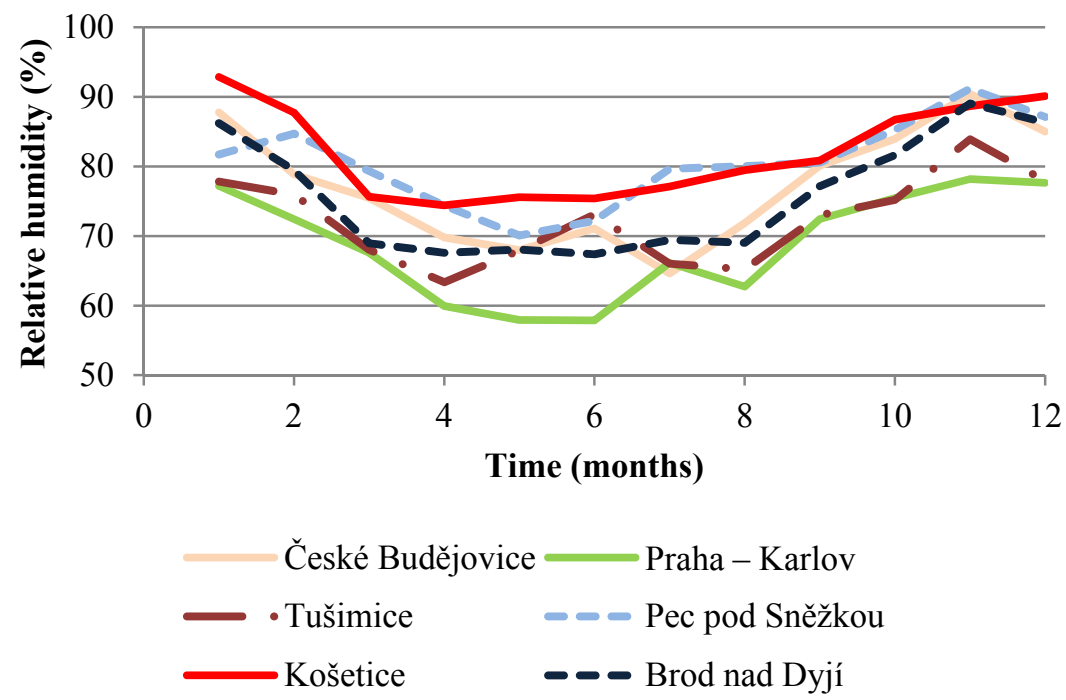

Figure 2: Average monthly values of relative humidity. 

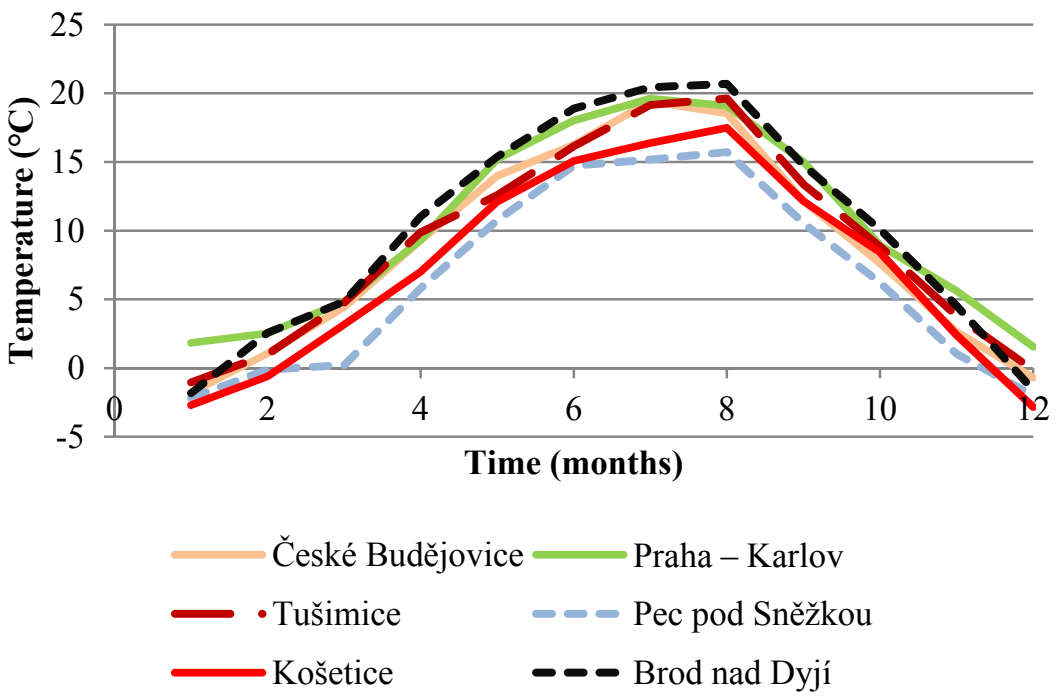

Figure 3: Average monthly values of temperature.

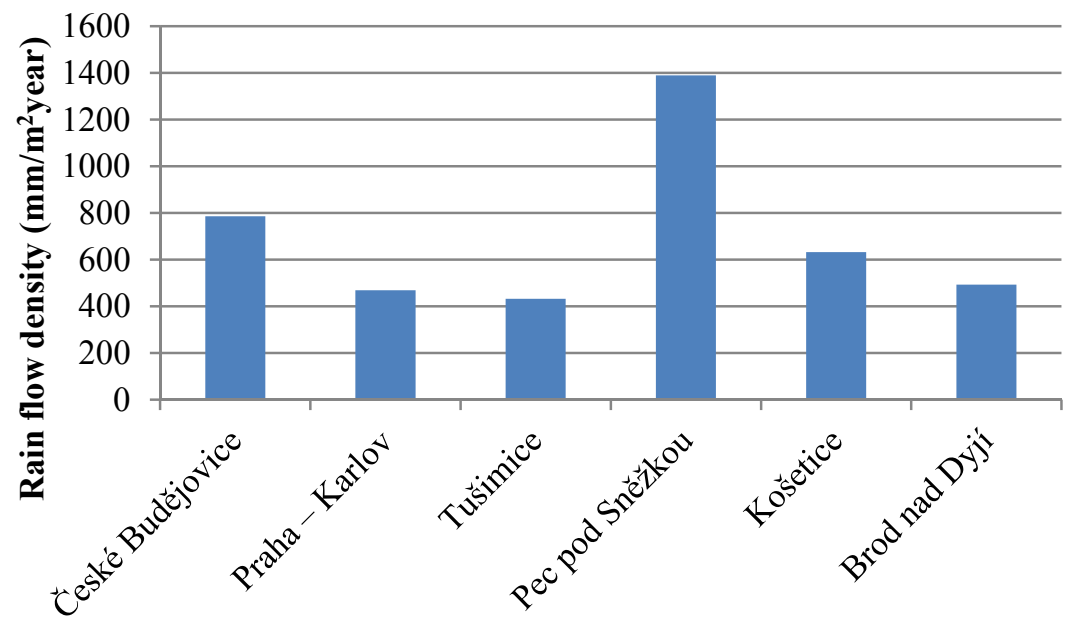

Name of station

Figure 4: Yearly amount of precipitation. 


\section{Results and discussion}

The results of computational simulations performed by SIFEL code are presented below. All the computer simulations were accomplished for 10 years in order to ensure steady conditions in the studied walls.

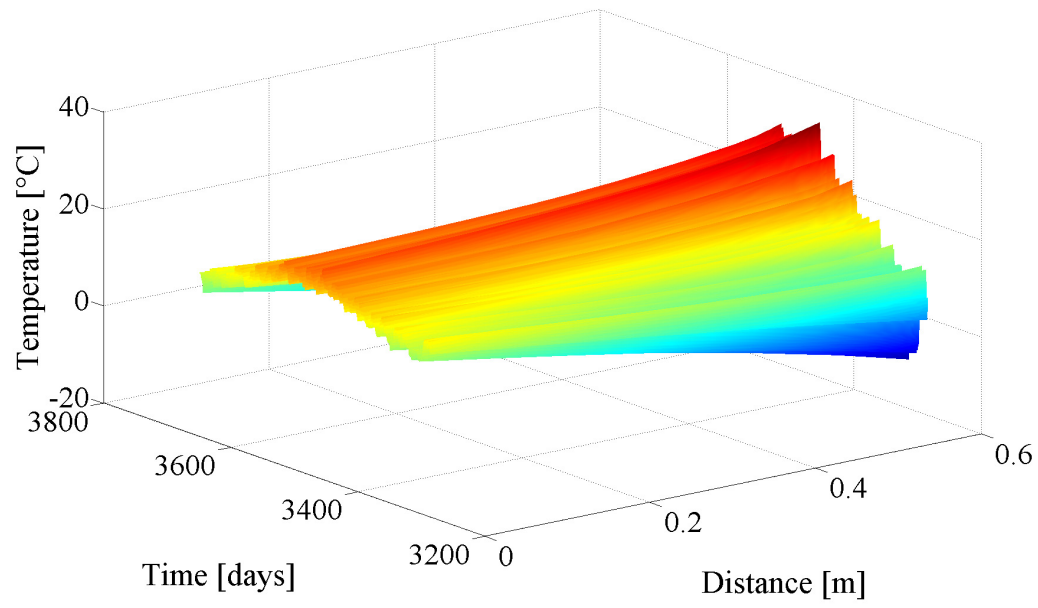

Figure 5: Temperature distribution in SL sandstone as a function of time and space (location Pec p. Sněžkou).

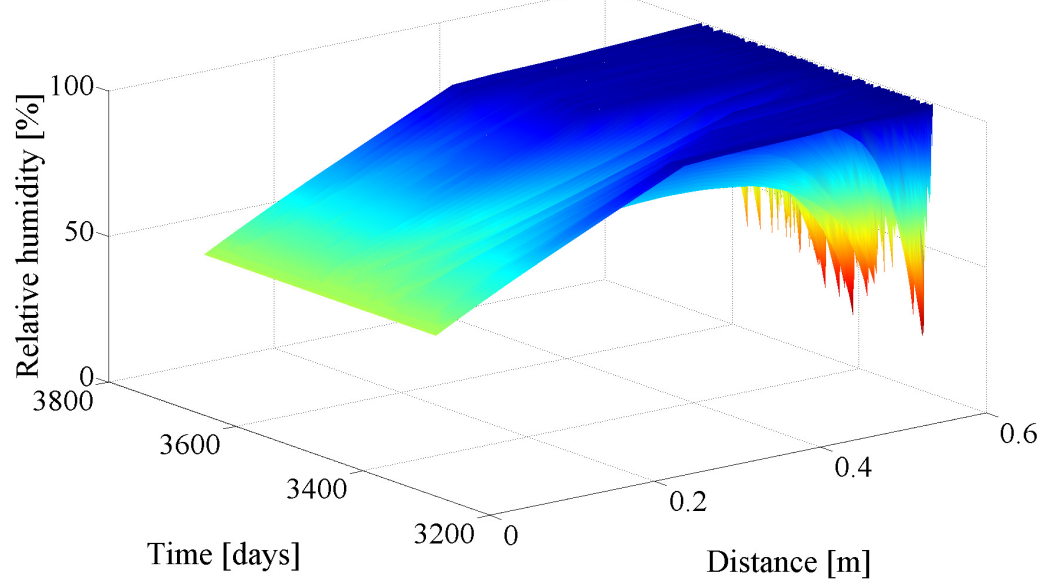

Figure 6: Relative humidity distribution in SL sandstone as a function of time and space (location Pec p. Sněžkou). 
Just for illustration, temperature and relative humidity as a function of time and space during the last, $10^{\text {th }}$ year of the simulation are shown in Figs 5 and 6. The hygrothermal response of each studied construction was analyzed in order to determine the effect of the studied environment on the degradation of historical masonry. During the service life, the constructions are exposed to a range of physical, chemical and mechanical stresses. The amount of moisture that is retained in the construction significantly affects the durability of the construction. However, the amount of moisture in the construction does not result from environmental conditions only, the material composition plays significant role as well $[6,13]$. The ability of construction materials to transfer loads depends on the magnitude of applied stresses, moisture contents and temperatures. In order to quantify the damage that is caused to the construction, it is necessary to employ the damage function. The choice of particular damage function should be done with respect to the investigated material, its characteristic type of damage and the ambient environment in order to obtain credible results. There are described several damage functions in the literature, for example, Time-of-Wetness (TOW) [14], RHT-Index [15], Mold-GrowthIndex [16, 17], Winter index [18] etc. In this paper, RHT-Index, TOW and Winter index was used to quantify the damage caused to the investigated constructions. The brief description of selected damage functions is given below.

TOW is one of the standard damage functions. TOW was used in various engineering tasks in various ways. In this paper, the TOW is calculated as a time in hours during a year where both the temperature and relative humidity were above the prescribed levels. The value of TOW ranges between 0 and 8760 . The prescribed levels in the research were set to $0^{\circ} \mathrm{C}$ and $95 \%$ of relative humidity.

The RHT-Index is similar to TOW, but instead of calculating only time when the prescribed conditions are met, RHT-Index places emphasis on the rate of exceeding the prescribed values of temperature and relative humidity. RHTIndex is calculated only if $T>T_{0}$ and $R H>R H_{0}$ according to

$$
\mathrm{RHT}=\sum\left(\mathrm{T}-\mathrm{T}_{0}\right) \cdot\left(\mathrm{RH}-\mathrm{RH}_{0}\right)
$$

where $T_{0}=0^{\circ} \mathrm{C}$ and $R H_{0}=95 \%$ are the prescribed values.

Winter index (WI) damage function was designed for such locations where the typical damage is caused by alternation of freezing and thawing periods:

$$
\mathrm{WI}=\sum\left(\mathrm{T}-\mathrm{T}_{0}\right) \cdot\left(\mathrm{RH}-\mathrm{RH}_{0}\right) .
$$

In principle, the method is based on RHT-Index calculations, but the definition of prescribed values is different. As the WI should describe the induced frost in the building envelopes, the $T_{0}$ is equal to an equilibrium temperature of water-ice phase change and $\mathrm{RH}_{0}$ corresponds to the maximum hygroscopic moisture content of porous building materials. Due to safety reasons, the values of $T_{0}$ and $R H_{0}$ were set to $0^{\circ} \mathrm{C}$ and $95 \%$ respectively, despite the fact that freezing point of water in porous building materials is lower than $0^{\circ} \mathrm{C}$ and the condensation of water vapor occurs when the relative humidity is above $97 \%$. The WI is calculated only if $T<T_{0}$ and $R H>R H_{0}$. The value of WI 
is always negative, the lower value WI returns, the more severe damage conditions were in the studied material.

All of the studied sandstone masonries were analyzed using above mentioned damage functions. The point of investigation was placed $2 \mathrm{~mm}$ under the exterior surface of the masonry. The analysis was done for the last year of the simulation. Moreover, for each studied wall the maximum freezing depth (from exterior surface) where the possible freezing of water may occur was identified (MFD).

The analysis presented in Table 4 shows that the most severe environmental conditions were typical for location of Pec p. Sněžkou. The values of WI for that

Table 4: Analysis of hygrothermal response of studied stone masonries.

\begin{tabular}{|c|c|c|c|c|c|c|}
\hline \multirow{2}{*}{ Location } & \multirow[b]{2}{*}{ Damage } & \multicolumn{5}{|c|}{ Materials } \\
\hline & & $\mathrm{SH}$ & SB & SK & SL & $\mathrm{SZ}$ \\
\hline \multirow{4}{*}{$\begin{array}{c}\text { České } \\
\text { Budějovice }\end{array}$} & WI & -390 & -338 & -390 & -456 & -109 \\
\hline & TOW & 1192 & 1159 & 1149 & 1222 & 977 \\
\hline & RHT & 10328 & 10231 & 11748 & 11515 & 5704 \\
\hline & MFD & $150 \mathrm{~mm}$ & $200 \mathrm{~mm}$ & $100 \mathrm{~mm}$ & $150 \mathrm{~mm}$ & $200 \mathrm{~mm}$ \\
\hline \multirow{4}{*}{ Košetice } & WI & -78 & -57 & -49 & -86 & -9 \\
\hline & TOW & 1331 & 1290 & 1308 & 1380 & 964 \\
\hline & RHT & 13784 & 13559 & 15940 & 15767 & 4720 \\
\hline & MFD & $200 \mathrm{~mm}$ & $75 \mathrm{~mm}$ & $150 \mathrm{~mm}$ & $200 \mathrm{~mm}$ & $40 \mathrm{~mm}$ \\
\hline \multirow{4}{*}{$\begin{array}{l}\text { Pec p. } \\
\text { Sněžkou }\end{array}$} & WI & -903 & -790 & -776 & -1045 & -210 \\
\hline & TOW & 2561 & 2407 & 2612 & 2770 & 2362 \\
\hline & RHT & 60112 & 61131 & 75832 & 73331 & 25561 \\
\hline & MFD & $200 \mathrm{~mm}$ & $125 \mathrm{~mm}$ & $200 \mathrm{~mm}$ & $250 \mathrm{~mm}$ & $100 \mathrm{~mm}$ \\
\hline \multirow{4}{*}{$\begin{array}{l}\text { Praha - } \\
\text { Karlov }\end{array}$} & WI & -130 & -116 & -142 & -171 & -45 \\
\hline & TOW & 110 & 106 & 102 & 117 & 63 \\
\hline & RHT & 724 & 712 & 817 & 880 & 299 \\
\hline & MFD & $20 \mathrm{~mm}$ & $50 \mathrm{~mm}$ & $15 \mathrm{~mm}$ & $20 \mathrm{~mm}$ & $20 \mathrm{~mm}$ \\
\hline \multirow{4}{*}{ Tušimice } & WI & 0 & 0 & 0 & 0 & 0 \\
\hline & TOW & 250 & 243 & 238 & 263 & 189 \\
\hline & RHT & 2630 & 2613 & 3043 & 3005 & 1569 \\
\hline & MFD & $0 \mathrm{~mm}$ & $0 \mathrm{~mm}$ & $0 \mathrm{~mm}$ & $0 \mathrm{~mm}$ & $0 \mathrm{~mm}$ \\
\hline \multirow{4}{*}{$\begin{array}{c}\text { Brod n. } \\
\text { Dyjí }\end{array}$} & WI & -177 & -136 & -123 & -195 & -43 \\
\hline & TOW & 958 & 931 & 952 & 993 & 780 \\
\hline & RHT & 11746 & 11574 & 13533 & 13372 & 6092 \\
\hline & MFD & $150 \mathrm{~mm}$ & $100 \mathrm{~mm}$ & $50 \mathrm{~mm}$ & $200 \mathrm{~mm}$ & $100 \mathrm{~mm}$ \\
\hline
\end{tabular}


location ranged from -210 to -1045 , which was significantly higher than for other localities. The same rule applied for other studied damage parameters in this location. Contrary to Pec p. Sněžkou, the location of Tušimice proved the lowest damage conditions for historical masonry. The water-ice phase change in the material was practically disproved, which was affirmed by zero values of WI and MFD. On the other hand, the values of RHT were above the average which proved propitious conditions in terms of frost resistance during the winter period.

By comparing the results obtained for the studied sandstones it can be concluded that the best hygrothermal performance and durability was achieved with the sandstone from Záměl quarry (SZ). The worst performance could be registered in the case of sandstone from Libnava quarry (SL).

\section{Conclusions}

In this paper, the hygrothermal analysis of five selected sandstones under five different environments was carried out. Such analysis allows studying the effect of different climatic conditions on the degradation of historical masonry in the Czech Republic. For the analysis of hygrothermal response of studied constructions several damage functions were used. The result of that analysis proved significant impact of the environment on degradation of historical masonry. More to that, the analysis can be used as a comparative study of different kinds of sandstones.

In order to make the analytical results more valuable, it would be preferable to implement more damage aspects or to involve coupled hygro-thermomechanical model. Such a model allows investigation of crack formations which have significant impact on further hygrothermal performance. Having hygrothermo-mechanical model, the estimation of service life may be done more precisely, which can be subsequently included as one of the evaluation method for investigation of the effect of environmental conditions on the degradation of historical masonry.

\section{Acknowledgement}

This research has been supported by the Ministry of Culture of the Czech Republic, under project No DF12P01OVV030.

\section{References}

[1] Kočí, J., Kočí, V., Maděra, J., Rovnaníková, P., Černý, R., Computational analysis of hygrothermal performance of renovation renders. WIT Transactions on Engineering Sciences, 68, pp. 267-277, 2010.

[2] Maděra, J., Kočí, V., Vejmelková, E., Černý, R., Rovnaníková, P., et al., Influence of material characteristics of concrete and thermal insulation on the service life of exterior renders. WIT Transactions on Modelling and Simulation, 48, pp. 13-23, 2009. 
[3] Lu, G., Lu, G.Q., Xiao, Z.M., Mechanical properties of porous materials. Journal of Porous Materials, 6, pp. 359-368, 1999.

[4] Larbi, J.A. Microscopy applied to the diagnosis of the deterioration of brick masonry. Construction and Building Materials, 18, pp. 299-307, 2004.

[5] Maděra, J., Kočí, J., Černý, R., A complex finite-element model for investigation of historical masonry. WIT Transactions on the Built Environment, 131, pp. 221-231, 2013.

[6] Kočí, J., Maděra, J., Rovnaníková, P., Černý, R., Hygrothermal performance of innovative renovation renders used for different types of historical masonry. WIT Transactions on the Built Environment, 118, pp. 683-693, 2011.

[7] Künzel, H. M., Simultaneous Heat and Moisture Transport in Building Components, PhD Thesis, IRB Verlag Stuttgart, 1995.

[8] Ďurana, K., Kočí, J., Maděra, J., Pokorný, J., Černý, R., Modification of the computational model of coupled heat and moisture transport: the transition between the liquid and gaseous phases of water. AIP Conference Proceedings, 2014, in press.

[9] Kruis, J., Koudelka, T., Krejčí, T., Efficient computer implementation of coupled hydro-thermo-mechanical analysis. Mathematics and Computers in Simulation, 80, pp. 1578-1588, 2010.

[10] Vejmelková, E., Keppert, M., Reiterman, P., Černý, R., Mechanical, hygric and thermal properties of building stones. WIT Transactions on The Built Environment, 131, pp. 357-367, 2013.

[11] Kočí, V., Maděra, J., Fořt, J., Žumár, J., Pavlíková, M., et al., Service Life Assessment of Historical Building Envelopes Constructed Using Different Types of Sandstone: A Computational Analysis Based on Experimental Input Data. The Scientific World Journal, 2014, pp. 1-12, 2014.

[12] Ďurana, K., Maděra, J., Černý, R., Database of climatic data as a rewarding tool for inclusion of weather observations in computational service life assessments of historical buildings. WIT Transactions on the Built Environment, 131, pp. 245-256, 2013.

[13] Maděra, J., Kočí, V., Černý, R., Effect of thermal insulation on hygric and thermal conditions in the envelopes of renovated historical buildings. WIT Transactions on Engineering Sciences, 75, pp. 281-292, 2012.

[14] Salonvaara, M., Sedlbauer, K., Holm, A., Pazera, M., Effect of selected weather year for hygrothermal analyses. Buildings XI, Thermal Performance of the Exterior Envelopes of Whole Buildings XI, Proceedings CD-ROM, Clearwater Beach, Florida, Atlanta, GA: ASHRAE, 2010.

[15] Mukhopadhyaya, P., Kumaran, K., Tariku, F., Van Reenen, D., Application of Hygrothermal Modeling Tool to Assess Moisture Response of Exterior Walls. Journal of Architectural Engineering, 12(4), pp. 178186, 2006. 
692 Structural Studies, Repairs and Maintenance of Heritage Architecture XIV

[16] Sedlbauer, K., Prediction of mould fungus formation on the surface of and inside building components. Ph.D. Thesis, Fraunhofer Institute for Building Physics, 2002.

[17] Hukka, A., Viitanen, H., A mathematical model of mould growth on wooden material. Wood Science and Technology, 33(6), pp. 475-485, 1999.

[18] Kočí, J., Maděra, J., Černý, R., Generation of a critical weather year for hygrothermal simulations using partial weather data sets. Building and Environment, 76, pp. 54-61, 2014. 